\title{
STUDI EFEKTIFITAS DESINFEKSI DAN STERILISASI DALAM MENURUNKAN ANGKA KUMAN ALAT SET MEDIKASI DI RUMAH SAKIT WIJAYAKUSUMA PURWOKERTO TAHUN 2015
}

\author{
Mamay Maryani' ${ }^{1)}$, Tri Cahyono ${ }^{2)}$ \\ Jurusan Kesehatan Lingkungan Poltekkes Kemenkes Semarang \\ Jl. Raya Baturaden KM 12 Purwokerto, Indonesia.
}

\begin{abstract}
Abstrak
Upaya mencegah terjadinya infeksi nosokomial dari alat medis salah satunya yaitu dengan proses sterilisasi. Di Rumah Sakit Wijayakusuma Purwokerto terdapat proses desinfeksi cara kimia dan pemanasan panas basah. Tujuan penelitian ini untuk mengetahui efektifitas desinfeksi dan sterilisasi untuk menurunkan angka kuman alat set medikasi. Jenis penelitian yang digunakan adalah penelitian observasional analitik dengan pendekatan cross sectional. Sampel yang diambil yaitu 5 alat medis. Analisis data menggunakan uji Friedman. Hasil pemeriksaan, rata-rata angka kuman alat set medikasi sebelum desinfeksi $450 \mathrm{koloni} / \mathrm{cm}^{2}$, sesudah desinfeksi $10 \mathrm{koloni} / \mathrm{cm}^{2}, \mathrm{dan}$ sesudah pemanasan $1 \mathrm{koloni} / \mathrm{cm}^{2}$. Analisis data statistik dengan uji Friedmen didapatkan untuk tahap sebelum desinfeksi dengan sesudah desinfeksi yaitu 0,043 sehingga ada perbedaan angka kuman antara sebelum dan sesudah desinfeksi.Nilai $p$ untuk tahap sebelum desinfeksi dengan sesudah sterilisasi yaitu 0,043 sehingga ada perbedaan angka kuman antara sebelum desinfeksi dan sesudah sterilisasi. Nilai p untuk tahap sesudah desinfeksi dengan sesudah sterilisasi yaitu 0,655 sehingga tidak ada perbedaan angka kuman antara sesudah desinfeksi dan sesudah sterilisasi, efektifitas desinfeksi 96\% dan sterilisasi 99,67\%. Peneliti menyimpulkan efektifitas desinfeksi 96\% dan sterilisasi $99,67 \%$. Peneliti menyarankan untuk peneliti selanjutnya agar lebih teliti dalam pengambilan dan penanaman sampel agar tidak terjadi kontaminasi.
\end{abstract}

Kata Kunci : Rumah Sakit, Kuman, Desinfeksi, Sterilisasi, kesehatan lingkungan.

\begin{abstract}
Effectiveness Study of Disinfection and Sterilization in Reducing Germs Number on the medications tool set in Wijayakusuma Hospital Purwokerto Year of 2015. The Efforts to prevent medical tool set nosocomial infection was the sterilization process that include disinfection with chemical treatment and wet heating process. The research objective was determining the sterilization effectiveness reduce germs number on the medications tool set.The research design used was analytic observational study with cross sectional approach. The research samples were taken from medication tool set consisting 5 medical. Statistical analysis used was Friedman test. The research result shows that the average bacteria number before medication tool sets disinfection was $450 \mathrm{colonies} / \mathrm{cm}^{2}$, and after disinfection was 10 colonies $/ \mathrm{cm}^{2}$, and after the heating process was $1 \mathrm{colonie} / \mathrm{cm}^{2}$. The statistical data analysis using Friedman test obtained $p$ value 0.043 so there was significant bacteria number difference before and after disinfection process. $p$ value before disinfection and after the sterilization was 0.043 so there was significant difference between bacteria number before disinfection and after sterilization. $p$ value after disinfection and after sterilization was 0.655 so there was no significant bacteria number difference after disinfection and after sterilization.Researcher concluded that disinfectant reduce germs number up to $96 \%$ and sterilitation reduce germs number up to $99.67 \%$. The proposed suggestion was the next researcer to more carefull to prevent contamination.
\end{abstract}

Keywords : Hospital, Germ, disinfection, sterilization, environtmental health

\section{PENDAHULUAN}

Infeksi nosokomial atau disebut juga Hospital Acquired Infection (HAI) adalah infeksi yang didapatkan dan berkembang selama pasien di rawat di rumah sakit (WHO, 2004).

Kejadian Infeksi nosokomial di RSUD Setjonegoro kabupaten Wonosobo mengalami peningkatan dari tahun 2010 ada 0,37 \% kasus, dan tahun 2011 ada 1,48 \% kasus. (Nugraheni ratna, 2012). Laporan RSUP Dr. Sardjito Yogyakarta infeksi nosokomial tahun 2010 sebesar 7,95\%,RSUP

1) Email : mamay.maryani@gmail.com

2) Email : statistikan@yahoo.com
Dr. Wahidin Sudirohusodo terdapat kejadian infeksi nosokomial pada trimester III tahun 2010 sebesar $4,4 \%$.

Proses desinfeksi dan sterilisasi yang baik merupakan salah satu upaya untuk mencegah terjadinya infeksi nosokomial yang disebabkan oleh peralatan medis yang tidak steril. Proses sterilisasi alat medis di Rumah Sakit Wijayakusuma Purwokerto menggunakan autoclave yang sebelumnya telah dilakukan desinfeksi menggunakan chlorin. Prosedur sterilisasi alat medis dengan 
menggunakan autoclave dibutuhkan waktu 30 menit. Namun proses sterilisasi hanya 2 menit. Padahal proses sterilisasi dengan menggunakan autoclave minimal dilakukan 10 - 20 menit (Indan Entjang, 2003 ).

Tujuan penelitian adalah untuk mengetahui efektifitas desinfeksi dan streilisasi pada alat set medikasi di Rumah Sakit Wijayakusuma Purwokerto.

\section{BAHAN DAN METODE}

Penelitian ini menggunakan observasional analitik dengan pendekatan cross sectional. Sampel yang diambil menggunakan metode purposive sampling. artinya teknik pengambilan sesuai dengan kehendak peneliti sesuai dengan tujuan penelitian. Sampel yang diambil peneliti 5 buah alat yaitu pinset anatomis, sirek, klempean, nakuder dan gunting jaringan. Alasan peneliti mengambil sampel alat medis tersebut karena alat tersebut sering digunakan untuk melakukan pembedahan. Analisa data dengan uji Friedman.

\section{III.HASIL DAN PEMBAHASAN}

\section{Hasil}

Rata-rata jumlah kuman sebelum desinfeksi yaitu $450 \mathrm{koloni} / \mathrm{cm}^{2}$ dengan angka kuman tertinggi pada nakuder yaitu $1.100 \mathrm{koloni} / \mathrm{cm}^{2}$ dan yang terendah pada klempean yaitu $50 \mathrm{koloni} / \mathrm{cm}^{2}$.

Rata-rata jumlah kuman sesudah sterilisasi yaitu $10 \mathrm{koloni} / \mathrm{cm}^{2}$ dan ditemukan kuman pada gunting jaringan yaitu $50 \mathrm{koloni} / \mathrm{cm}^{2}$.

Rata-rata jumlah kuman sesudah sterilisasi yaitu 1 koloni/cm² dan masih ditemukan kuman pada sirek yaitu $5 \mathrm{koloni} / \mathrm{cm}^{2}$. Analisis uji friedman menunjukan hasil bahwa ada perbedaan angka kuman sebelum dan sesudah desinfeksi, sebelum desinfeksi dan sesudah sterilisasi dan tidak ada perbedaan angka kuman sesudah desinfeksi dan sesudah sterilisasi. Rata-rata efektifitas desinfeksi $96 \%$ dan sterilisasi 99,67\%.

\section{Pembahasan}

Jumlah kuman tertinggi pada tahap sebelum desinfeksi pada nakuder karena nakuder berfungsi menjepit jarum jahit pada luka terbuka dalam pembedahan. Penggunaan nakuder berulang kali sehingga nakuder mempunyai jumlah angka kuman yang tertinggi. Angka kuman yang terendah pada klempean karena klempean berfungsi menjepit pembuluh darah. Darah dan jaringan adalah steril. Sehingga klempean mempunyai jumlah angka kuman yang terendah.

Tahap setelah desinfeksi masih terdapat kuman pada gunting jaringan karena prinsip dasar dari desinfeksi yaitu mengurangi jumlah mikroorganisme penyebab penyakit. Kemudian pada gunting jaringan proses pengurangan tersebut tidak sempurna sehingga masih ditemukan kuman.
Tahap sesudah sterilisasi masih terdapat kuman pada sirek karena terjadi kontaminasi pada saat pengambilan dan penanaman sampel.

Terdapat perbedaan angka kuman pada tahap sebelum dan sesudah desinfeksi karena pada tahap sesudah desinfeksi alat medis bereaksi dengan bahan kimia sehingga terjadi penurunan angka kuman hingga 0 , terdapat perbedaan angka kuman pada tahap sebelum desinfeksi dan sesudah sterilisasi karena pada tahap sesudah sterilisasi alat medis kontak dengan uap panas sehingga terjadi penurunan angka kuman hingga 0 , tidak terdapat perbedaan angka kuman pada tahap sesudah desinfeksi dan sesudah sterilisasi karena terjadi penurunan jumlah kuman sama yaitu hampir 0 .

Efektifitas desinfeksi pada gunting jaringan tidak 100\% karena pada tahap sesudah desinfeksi masih terdapat kuman sehingga mempengaruhi efektifitasnya. Efektifitas sterilisasi pada sirek tidak 100\% karena pada tahap sesudah sterilisasi masih terdapat kuman sehingga mempengaruhi efektifitasnya.

\section{IV.KESIMPULAN}

Rata-rata jumlah kuman sebelum desinfeksi yaitu 450 koloni $/ \mathrm{cm}^{2}$. Rata-rata jumlah kuman sesudah desinfeksi yaitu $10 \mathrm{koloni} / \mathrm{cm}^{2}$. Rata-rata jumlah kuman sesudah sterilisasi yaitu $1 \mathrm{koloni} / \mathrm{cm}^{2}$. Analisis uji friedman didapatkan bahwa ada perbedaan angka kuman pada tahap sebelum desinfeksi dengan sesudah desinfeksi, ada perbedaan angka kuman pada tahapsebelum desinfeksi dan sesudah sterilisasi dan tidak ada perbedaan angka kuman pada tahap sesudah desinfeksi dan sesudah sterilisasi. Rata-rata efektivitas desinfeksi 96\% dan rata-rata efektivitas sterilisasi 99,6\%. Peneliti menyarankan untuk peneliti selanjutnya agar lebih teliti dalam penanaman dan pengambilan sampel agar tidak terjadi kontaminasi.

\section{UCAPAN TERIMA KASIH}

Peneliti mengucapkan terima kasih kepada Rumah Sakit Wijayakusuma Purwokerto dan Poltekkes Kemenkes Semarang, sehingga penelitian ini dapat terselesaikan.

\section{DAFTAR PUSTAKA}

Catur Wahyuni Agus Rintina. (2012). Studi Efektivitas Proses Sterilisasi dalam Menurunkan Angka Kuman pada Alat Set Medikasi di Rumah Sakit PKU Muhammadiyah Gombong Tahun 2012. KTI. Purwokerto : Kementerian Kesehatan RI Politeknik Kesehatan Semarang Jurusan Kesehatan Lingkuungan Purwokerto.

Darmadi. (2008). Infeksi Nosokomial Problematika dan Pengendaliannya. Jakarta : Salemba Medika. 
Depkes RI. (2004). Tentang Persyaratan Kesehatan Lingkungan Rumah Sakit (Kepmenkes RI. No. 1204/MENKES/SK/2004). Jakarta : Depkes RI.

Depkes RI. (2009). Undang-undang Republik Indonesia No. 44 Tahun 2009. Jakarta : Depkes RI.

Indang Entjang. (2003). Mikrobiologi dan Parasitologi. Bandung : PT. Citra Aditya Bakti.

Kepmenkes RI. (2009). Undang-undang Republik Indonesia Nomor 362009 tentang Kesehatan. Jakarta : Kepmenkes RI.

Komunitas dan Perpustakaan Online Indonesia. (2006). At http://organisasi.org/definisipengertian-kuman_penyebab-penyakit-dangangguan-kesehatan.

Laporan Satuan Rumkit TK II 04.06.01/Wijayakusuma 2014.

Lud Waluyo. (2007). Mikrobiologi Umum Cetakan Ketiga. Malang : UMM Press Universitas Terbuka.

Pelezar MJ dan ECS Chan, 1988 Dasar-dasar Mikrobiologi 2, Jakarta : UI Press
Nugraheni Ratna. (2012). Studi Prevlensi Angka Kejadian Infeksi Nosokomial di RSUD Setjonegoro Kabupaten Wonosobo (Data Sekunder dari Bulan Juli 2009-Desember 2011). Thesis. Semarang : Universitas Diponegoro.

Nurwahyu Ningrum. (2009). Studi Sanitasi Alat Makan di Instalasi Gizi RSUD Kebumen Tahun 2009. KTI. Purwokerto : Kementerian Kesehatan RI Politeknik Kesehatan Semarang Jurusan Kesehatan Lingkungan Purwokerto.

S. Purwanto, dkk. (1997). Buku Pedoman Praktek. Purwokerto : Departemen Kesehatan RI Akademi Kesehatan Lingkungan Purwokerto.

Srikandi Fardiaz. (1992). Mikrobiologi Pangan I. Jakarta : Gramedia Pustaka Utama.

Sriyati. (2009). Dekontaminasi Peralatan Kesehatan Habis Pakai.

At http://www.sterilisasi.com/wpcontent/uploads/2011/08/Dekontaminasi-AlatKesehatan-Habis-pakai.pdf.

Tri Cahyono. (2014). Pedoman Penulisan Proposal Penelitian dan Karya Tulis Ilmiah/ Skripsi Edisi Revisi Ketiga. Purwokerto ; Kementerian Kesehatan RI Politeknik Kesehatan Semarang Jurusan Kesehatan Lingkungan Purwokerto. 